\title{
Effect of Aggregate Properties on the Crushing Strength of Concrete
}

\author{
Mishuk Bhattacharjee ${ }^{1}$, Md. Arifur Rahman ${ }^{2}$, Muhammad Ashrafuzzaman ${ }^{2}$, Shovon Barua $^{2}$ \\ ${ }^{1}$ Department of Civil Engineering, Rajshahi University of Engineering \& Technology (RUET), Rajshahi, Bangladesh \\ ${ }^{2}$ Department of Civil Engineering, Chittagong University of Engineering and Technology (CUET), Chittagong, Bangladesh
}

\section{Email address:}

mishukbhattacharjeebd@gmail.com (Mishuk Bhattacharjee), arifrahman1278@gmail.com (Md. Arifur Rahman), showrav512@gmail.com(Muhammad Ashrafuzzaman), Shovon.barua80@gmail.com (Shovon Barua)

\section{To cite this article:}

Mishuk Bhattacharjee, Md. Arifur Rahman, Muhammad Ashrafuzzama, Shovon Barua. Effect of Aggregate Properties on the Crushing Strength of Concrete. International Journal of Materials Science and Applications. Vol. 4, No. 5, 2015, pp. 343-349.

doi: $10.11648 /$ j.ijmsa.20150405.19

\begin{abstract}
This paper studied the effect of aggregate properties on the crushing strength of concrete. In order to achieve the study objective, three types of coarse aggregates, brick khoa, shingles stone, and black stone were used to test. And the test results show that concrete made from black stone has the highest workability followed by shingles stone \& brick khoa of aggregates.
\end{abstract}

Keywords: Comparison of Aggregate Properties, Crushing Strength of Concrete, Sieve Analysis of Aggregates, Grain Size Distribution Curve, Strain Analysis, Strength-Strain Curve

\section{Introduction}

Aggregates are the important constituent in concrete. They give body to the concrete; reduce shrinkage and effect of economy. Earlier, aggregate were considered as chemically inert materials but now it has been recognized that some of the aggregates are chemically active and also that certain aggregates exhibit chemical bond at the interface of aggregate and paste. The mere fact, that the aggregates occupy 70-80 percent of the volume of concrete. Their impact on various characteristics and properties of concrete is undoubtedly considerable. To know more about the concrete it is very essential that one should know more about the aggregates which constitute such a major volume in concrete. Without the study of the aggregate in depth and range, the study of the concrete remains incomplete. Cement is the only factory made standard component in concrete. Other ingredients namely water and aggregates are natural materials and vary to any extent in many of their properties [6]. The objectives of this thesis work were: to determine the properties of aggregates, to determine the crushing strength of concrete, to compare various properties of aggregates on the crushing strength of concrete and to compare stress- strain diagram of various types of aggregate. Concrete can be considered as two phase materials for convenience; paste phase and aggregate phase. The aggregates can be studied encompassing following parameters [6]: i) Classification ii) Size iii) Texture iv) Source v) Shape vi) Specific gravity \& bulk density vii) Bulking factor viii) Soundness ix) Sieve analysis x) Strength xi) Moisture content xii) Chemical properties. Generally aggregates can be classified as (a) Normal weight aggregates, (b) Light weight aggregates \& (c) Heavy weight aggregates [6]. Again normal weight aggregates are classified as (a) Natural aggregates including Sand, Gravel, crushed Rock such as Granite, Quartzite, Basalt, Sandstone etc. and (b) artificial aggregates including broken brick, air cooled slag, sintered fly ash, bloated clay etc. The largest maximum size of aggregate particle to handle under a given set of conditions should be used. Perhaps $80 \mathrm{~mm}$ size is the maximum size that could be conveniently used for concrete making. Using the largest possible maximum size will result in (a) reduction of the cement content, (b) reduction in water requirement\& (c) reduction in drying shrinkage. Aggregates are divided into two categories from the consideration of size (a) coarse aggregate (b) fine aggregate. The size of aggregate bigger than $4.75 \mathrm{~mm}$ is considered as coarse aggregate and aggregate whose size is $4.75 \mathrm{~mm}$ and less is considered as fine aggregate [6]. The strength, durability and structural performance of concrete are 
greatly affected by the properties of fine and coarse aggregates (Ayubet al 2012; Joseph et al 2012) [9] [10]. There are some other properties, not dependent on parent rocks, particle size distribution, surface texture and absorption considerably influence the quality of concrete in fresh and hardened state (Neville, 2005; Akçaoglu et al. 2004; Basheer et al. 2005, Makani et al. 2010; Meddah et al. 2010) [2] [6] [14] [15] [16]. Surface texture is the property, the measure of which depends upon the relative degree to which particle surfaces are polished or dull, smooth or rough. Surface texture depends on hardness, grain size, pore structure, structure of the rock, and the degree to which forces acting on the particle surface have smoothed or roughed it. Hard, dense, fine grained materials will generally have smooth fracture surfaces. As surface smoothness increases, contract area decreases, hence polished particle will have less bonding area with the matrix than a rough particle of the same volume [1]. Almost all natural aggregate materials originate from bed rocks. There are three kinds of rocks, namely, igneous, sedimentary and metamorphic. These classifications are based on the mode of formation of rocks. It may be recalled that igneous rocks are formed by the cooling of molten magma or lava at the surface of the crest or deep beneath the crest. The sedimentary rocks are formed below the sea bed and subsequently lifted up. Metamorphic rocks are originally either igneous or sedimentary rocks which are subsequently metamorphosed due to extreme heat and pressure. The concrete making properties of aggregate are influenced to some extent on the basis of geological formation of the parent rocks together with the subsequent processes of weathering and alternation [6]. Thus many properties of the aggregate such as chemical and mineral composition, specific gravity, hardness, strength, physical and chemical stability and porosity depend on the properties of parent rocks (Tasonget al 1998; Elshariefet al 2003; Makani, 2011) [11][12][13].The shape of aggregate is an important characteristic since it affects the workability of concrete. It is difficult to really measure the shape of irregular body like concrete aggregates which are derived from various rocks. Not only will the characteristic of the parent rock, but also the type of crusher used influence the shape of aggregates. The shape of aggregates is very much influenced by the type of crusher and reduction ratio. Flat particles in concrete aggregates will have particularly objectionable effect on the workability requirement, strength and durability. In general, excessive flaky aggregate makes very poor concrete [6]. The properties (strength, durability, impermeability and workability) of concrete depend upon the following parameters [8]: i) Grading of the aggregates, ii) Moisture content of the aggregates, iii) Water/ cement ratio, iv) Proportioning of the various ingredients of concrete, v) Method of mixing, vi) Placing and compaction of concrete \& vii) Curing of concrete.

\section{Experimental Programme}

Commercially available Ordinary Portland Cement was used for this work purpose. This cement has a specific gravity of 3.15 [4]. Three types of coarse aggregates such as brick khoa; shingles stone; and black stone were used. The fine aggregate is coarse sand obtained from river. Preliminary laboratory investigation was conducted to ascertain the suitability of using the aggregates for construction work [4]. Potable drinking water obtained from Civil Engineering Laboratory, Rajshahi University of Engineering \&Technology, Rajshahi -6204, Bangladesh, was used for this work. This water is therefore suitable for concrete work [4]. Preliminary laboratory investigation was conducted to ascertain the suitability of using the aggregates for construction work. Tests conducted include sieve analysis, moisture content, crushing value, unit weight, and compressive strength of aggregate. Nominal mix $(1: 2: 4)$ was adopted for this work with 0.45 water cement ratio and mix compositions were calculated by absolute volume method. For three type of coarse aggregate 27 cylinder ( $150 \mathrm{~mm}$ dia.,300mm height) were cast to allow the compressive strength to be monitored at 7,14 , and 28 days [4].

\subsection{Sieve Analysis of Aggregates}

In the BS and ASTM standards, the sieve sizes are given in terms of the number of openings per inch. The number of openings per square inch is equal to the square of the number of the sieve. In the Indian Standard (IS 460- L962), the sieve are designed by the size of the aperture in $\mathrm{mm}$.

The complete sieve analysis can be divided into two parts; coarse analysis and fine analysis. An oven dried samples of aggregate into two fractions by sieving it through a 4.75 $\mathrm{mm}$ IS sieve. The portion retained on it $(+4.75 \mathrm{~mm}$ size $)$ is termed as the gravel fraction and is kept for the coarse analysis while the portion passing through it $(-4.75 \mathrm{~mm}$ size) is subjected to fine sieve analysis. For grading purpose, the sieve sizes normally used are: 75.0, 50.0, 37.5, 25.0, 19.0, $12.5,9.5,6.25,4.75,2.36,1.18 \mathrm{~mm}$ and 600,300 $150 \mu \mathrm{m}$. These sieves used for concrete aggregate consist of a series in which the clear opening of any sieve is approximately one half of the opening of the next larger sieve size. The BS test sieve sizes in imperial units for this series were as follows: $3 \mathrm{in} ., 1.5 \mathrm{in} ., 1 \mathrm{in}, 0.75 \mathrm{in} ., 0.5 \mathrm{in}$. , 0.25 in., No. 4, 8, 16, 20, 30, 50, 100, 200 sieving is performed by arranging the various sieves one over the other in the order of their mesh openings. Largest aperture sieve being kept as the top and the smallest aperture sieve at the bottom. A receiver is kept at the bottom and a cover is kept at the top of the whole assembly. The aggregate sample is put on the top sieve and whole assembly fitted on a sieve is on a sieve shaking machine. The amount of shaking depends upon the shape and the number of particles. At least 10 minutes of shaking is desirable for aggregates with small particles. The percentage of aggregates retained on each sieve is calculated on the basis of the total mass of 
aggregates sample taken and from these results, percentage passing through each sieve [7].

\subsubsection{Sieve Analysis of Brick Khoa}

Table 1. Value of percentage of passing of brick khoa.

\begin{tabular}{llll}
\hline $\begin{array}{l}\text { Sieve No. (with } \\
\text { size) }\end{array}$ & $\begin{array}{l}\text { Cumulative } \\
\text { weightretained }\end{array}$ & $\begin{array}{l}\text { Cumulative } \\
\text { weightof \% retained }\end{array}$ & $\begin{array}{l}\text { \% of } \\
\text { passing }\end{array}$ \\
\hline 1in. $(25.00 \mathrm{~mm})$ & 0 & 0 & 100 \\
$3 / 4$ in. $(19.00 \mathrm{~mm})$ & 1410 & 28.22 & 71.78 \\
$1 / 2$ in. $(12.50 \mathrm{~mm})$ & 3760 & 75.26 & 24.74 \\
$3 / 8$ in. $(9.50 \mathrm{~mm})$ & 4385 & 87.77 & 12.23 \\
$1 / 4$ in. $(6.25 \mathrm{~mm})$ & 4823 & 96.54 & 3.36 \\
No $4(4.75 \mathrm{~mm})$ & 4898 & 98.04 & 1.96 \\
No $8(2.36 \mathrm{~mm})$ & 4969 & 99.45 & 0.55 \\
No16(1.18 mm) & 4984 & 99.75 & 0.25 \\
No30 $(600 \mu \mathrm{m})$ & 4992 & 99.92 & 0.08 \\
No50 $(300 \mu \mathrm{m})$ & 4996 & 100 & 0 \\
& $\Sigma 39217$ & $\Sigma 784.95$ & \\
\hline
\end{tabular}

5000 gm brick khoa was sieved.

Fineness modulus of brick khoa $(\mathrm{FM})=39217 / 5000=7.84$.

Grain size distribution curve of brick khoa is shown in figure 1.

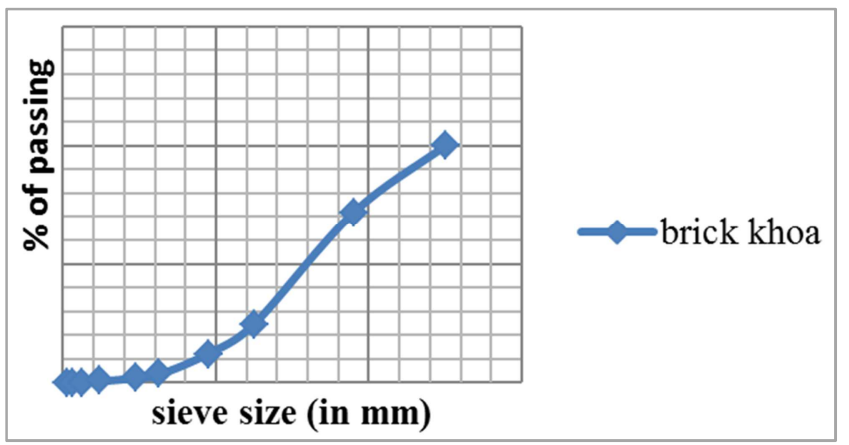

Figure No. 1. Grain size distribution curve of brick khoa.

\subsubsection{Sieve Analysis of Shingles Stone}

Table 2. Value of percentage of passing of shingles stone

\begin{tabular}{|c|c|c|c|c|c|}
\hline $\begin{array}{l}\text { Sieve No. (with } \\
\text { size) }\end{array}$ & \multicolumn{2}{|c|}{$\begin{array}{l}\text { Cumulative } \\
\text { weightretained }\end{array}$} & \multicolumn{2}{|c|}{$\begin{array}{l}\text { Cumulative } \\
\text { weightof \% retained }\end{array}$} & $\begin{array}{l}\text { \% of } \\
\text { passing }\end{array}$ \\
\hline 1 in. $(25.00 \mathrm{~mm})$ & \multicolumn{2}{|c|}{0} & \multicolumn{2}{|c|}{0} & 100 \\
\hline $3 / 4 \mathrm{in} .(19.00 \mathrm{~mm})$ & \multicolumn{2}{|l|}{828} & \multicolumn{2}{|l|}{16.61} & 83.39 \\
\hline $1 / 2$ in. $(12.50 \mathrm{~mm})$ & \multicolumn{2}{|l|}{4071} & \multicolumn{2}{|l|}{81.65} & 18.35 \\
\hline $3 / 8$ in. $(9.50 \mathrm{~mm})$ & \multicolumn{2}{|l|}{4726} & \multicolumn{2}{|l|}{94.80} & 5.20 \\
\hline $1 / 4$ in. $(6.25 \mathrm{~mm})$ & \multicolumn{2}{|l|}{4951} & \multicolumn{2}{|l|}{99.32} & 0.68 \\
\hline No $4(4.75 \mathrm{~mm})$ & \multicolumn{2}{|l|}{4962} & \multicolumn{2}{|l|}{99.54} & 0.46 \\
\hline No $8(2.36 \mathrm{~mm})$ & \multicolumn{2}{|l|}{4972} & \multicolumn{2}{|l|}{99.74} & 0.26 \\
\hline No16(1.18 mm) & \multicolumn{2}{|l|}{4978} & \multicolumn{2}{|l|}{99.86} & 0.14 \\
\hline No30 $(600 \mu \mathrm{m})$ & \multicolumn{2}{|l|}{4980} & \multicolumn{2}{|l|}{99.90} & 0.10 \\
\hline \multirow[t]{2}{*}{$\operatorname{No} 50(300 \mu \mathrm{m})$} & \multicolumn{2}{|l|}{4985} & \multicolumn{2}{|l|}{100} & 0 \\
\hline & $\Sigma 39453$ & $\begin{array}{l}\Sigma \\
791.42\end{array}$ & $\Sigma 791.42$ & $\Sigma 791.42$ & \\
\hline
\end{tabular}

5000 gm shingles stone was sieved.

Fineness modulus of shingles stone $(\mathrm{FM})=39453 / 5000=7.90$
Grain size distribution curve of shingles stone is shown in figure 2 .

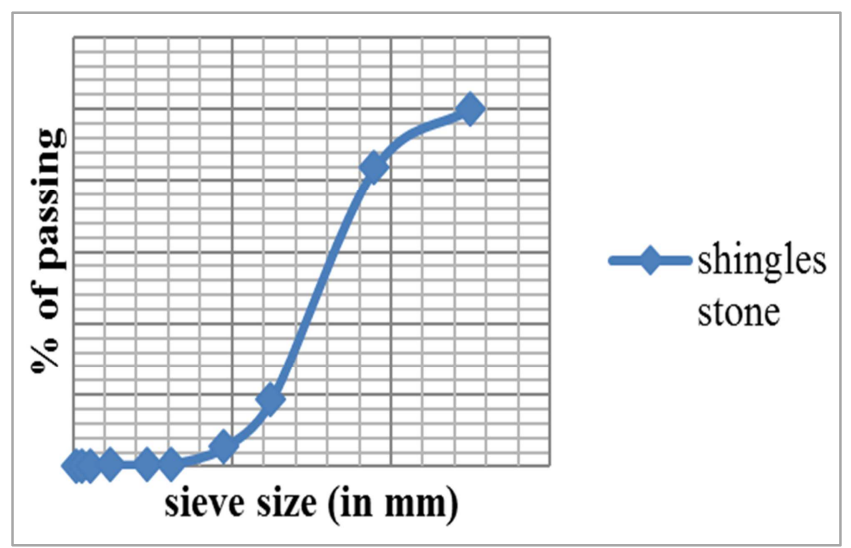

Figure No. 2. Grain size distribution curve of shingles stone.

\subsubsection{Sieve Analysis of Black Stone}

Table 3. Value of percentage of passing of black stone.

\begin{tabular}{llll}
\hline $\begin{array}{l}\text { Sieve No. (with } \\
\text { size) }\end{array}$ & $\begin{array}{l}\text { Cumulative } \\
\text { weight retained }\end{array}$ & $\begin{array}{l}\text { Cumulative weight } \\
\text { of \% retained }\end{array}$ & $\begin{array}{l}\text { \% of } \\
\text { passing }\end{array}$ \\
\hline 1in. $(25.00 \mathrm{~mm})$ & 0 & 0 & 100 \\
3/4 in. $(19.00 \mathrm{~mm})$ & 1017 & 20.38 & 79.62 \\
$1 / 2$ in. $(12.50 \mathrm{~mm})$ & 3862 & 77.39 & 22.61 \\
$3 / 8$ in. $(9.50 \mathrm{~mm})$ & 4662 & 93.43 & 6.57 \\
$1 / 4$ in. $(6.25 \mathrm{~mm})$ & 4917 & 98.54 & 1.46 \\
No $4(4.75 \mathrm{~mm})$ & 4937 & 98.94 & 1.06 \\
No $8(2.36 \mathrm{~mm})$ & 4957 & 99.34 & 0.66 \\
No16(1.18 mm) & 4977 & 99.74 & 0.26 \\
No30 $(600 \mu \mathrm{m})$ & 4980 & 99.80 & 0.20 \\
No50 $(300 \mu \mathrm{m})$ & 4990 & 100 & 0 \\
\hline
\end{tabular}

5000 gm black stone was sieved.

Fineness modulus of black stone $(\mathrm{FM})=39299 / 5000=7.86$.

Grain size distribution curve of black stone is shown in figure 3 .

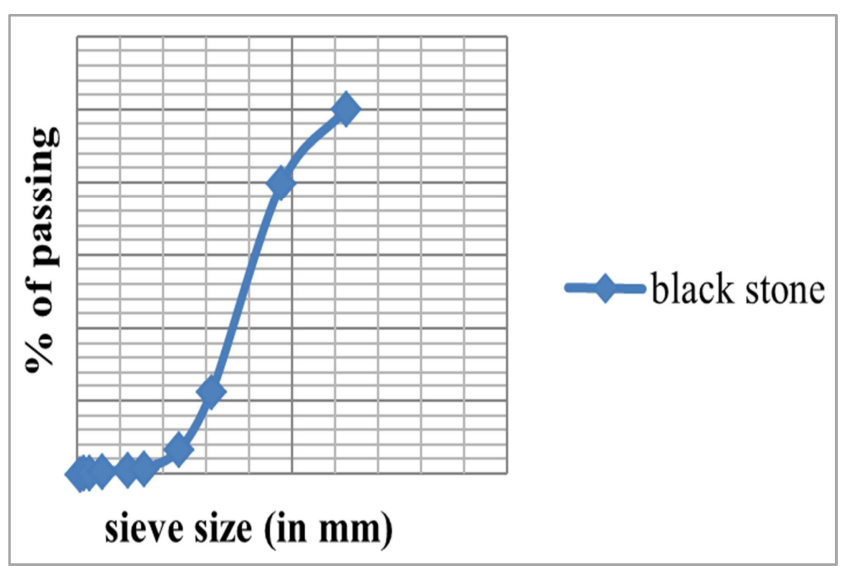

Figure No. 3. Grain size distribution curve of black stone. 


\subsubsection{Sieve Analysis of Coarse Sand}

Table 4. Value of percentage of passing of coarse sand.

\begin{tabular}{llll}
\hline Sieve No. (with size) & $\begin{array}{l}\text { Cumulative } \\
\text { weight retained }\end{array}$ & $\begin{array}{l}\text { Cumulative weight } \\
\text { of \% retained }\end{array}$ & $\begin{array}{l}\text { \% of } \\
\text { passing }\end{array}$ \\
\hline No $4(4.75 \mathrm{~mm})$ & 0 & 0 & 100 \\
No $8(2.36 \mathrm{~mm})$ & 4.6 & 0.95 & 99.04 \\
No16(1.18 mm) & 40.0 & 8.24 & 91.65 \\
No30 $(600 \mu \mathrm{m})$ & 279.9 & 57.63 & 37.81 \\
No50 $(300 \mu \mathrm{m})$ & 460.4 & 94.80 & 4.22 \\
No100 $(150 \mu \mathrm{m})$ & 485.7 & 100 & 0 \\
& $\Sigma 1270.6$ & $\Sigma 261.62$ & \\
\hline
\end{tabular}

500 gm coarse sand was sieved.

Fineness modulus of coarse sand $(\mathrm{FM})=261.62 / 100=2.62$

Grain size distribution curve of coarse sand is shown in figure 4.

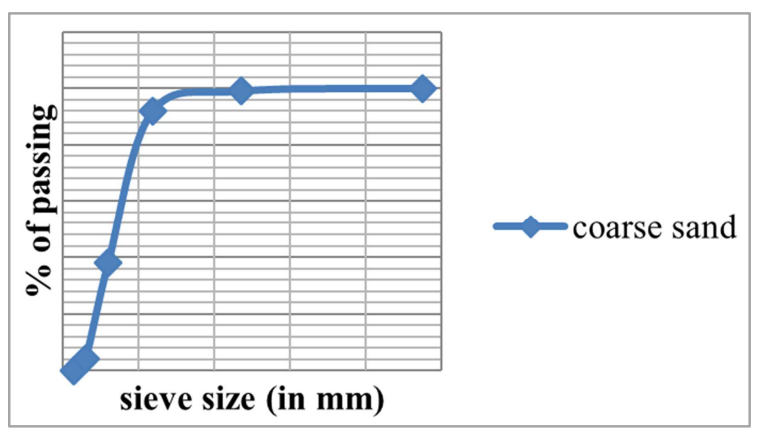

Figure No. 4. Grain size distribution curve of coarse sand.

\subsection{Test Programme for Experiment}

\subsubsection{Test for Determination of Crushing Value of Aggregate}

The aggregate crushing value gives a relative measure of the resistance of an aggregate to crushing under a gradually applied compressive load. With aggregates of "aggregate crushing value" 30 or higher, the result may be anomalous and in such cases the " $10 \%$ fines value" should be determined and used instead.

The standard aggregate crushing test is made on aggregate passing a $12.5 \mathrm{~mm}$ IS sieve and retained on $10 \mathrm{~mm}$ IS sieve. If required or if the standard size is not available other sizes up to $25 \mathrm{~mm}$ may be tested. But owing to the non homogeneity of the aggregates, the results will not be comparable, with those obtained in the standard test. About $5 \mathrm{~kg}$ of material consisting of aggregate passing $12.5 \mathrm{~mm}$ and retained on $10 \mathrm{~mm}$ sieve is taken. The aggregate in a surface dry condition is filled into the standard cylindrical measure in three layers approximately of equal depth. Each layer is temped 25 times with the temping rod and finally leveled off using the temping rod as straight edge. The weight of sample contained in the cylinder measure is taken (A). The same weight of the sample is taken for the subsequent repeat test. The cylinder of the test apparatus with aggregate filled in a standard manner is put in position on the base plate and the aggregate is carefully leveled and the plunger inserted horizontally on this surface. The plunger should not jam in the cylinder. The apparatus with the test sample and plunger in position is placed on the compression testing machine and is loaded uniformly up to a total load of 40 tons in 10 minutes time. The load is then released and the whole of the material removed from the cylinder and sieved on a $2.36 \mathrm{~mm}$ IS sieve. The fraction passing of the sieve is weighted (B).

The aggregate crushing value $=\mathrm{B} / \mathrm{A} \times 100$

Where, $\mathrm{B}=$ weight of fraction passing $2.36 \mathrm{~mm}$ sieve, $\mathrm{A}=$ weight of surface dry sample taken in mould.

The aggregate crushing value should not be more than $45 \%$ for aggregate used in concrete other than for wearing surfaces, and $30 \%$ for concrete used in wearing surfaces such as a runways, roads, and air field pavements.

Table 5. Crushing value of various type of aggregate

\begin{tabular}{llll}
\hline $\begin{array}{l}\text { Types of } \\
\text { aggregate }\end{array}$ & A (gm) & B (gm) & Crushing value(\%) \\
\hline Brick khoa & 2720 & 660 & 24.26 \\
Shingles stone & 3290 & 680 & 20.66 \\
Black stone & 3300 & 538 & 16.30 \\
\hline
\end{tabular}

\subsubsection{Test for Determination of Moisture Content of Aggregate}

Concrete mixes are designed on the basis of dry volumes of aggregates. The ratios used are the 'real mix ratio'. But in the field, the aggregates are generally wet, particularly when they are washed for clearing. So, moisture content must be determined of those and due allowance must be made in their volumetric measurement in the field. The correct ratios are then termed as "field mix ratios". For this, at first some of the aggregate was taken and wetted by water in 24 hours. Then the aggregate was weighted (A). Then the wetted aggregate was taken into the oven and dry the aggregates for 24 hours. Again the aggregate was weighted (B). These differences of two weights are expressed moisture content of the aggregates.

Moisture content of aggregate $=\mathrm{A}-\mathrm{B}$

Where, $A=$ Saturated weight of aggregate, \&

$\mathrm{B}=$ Oven dried (24 hour) weight of aggregate.

Table 6. Moisture content of various type of aggregate.

\begin{tabular}{llll}
\hline $\begin{array}{l}\text { Type of } \\
\text { aggregate }\end{array}$ & $\begin{array}{l}\text { Saturated } \\
\text { weight A } \mathbf{( g m})\end{array}$ & $\begin{array}{l}\text { Dry weight } \\
\text { B }(\mathbf{g m})\end{array}$ & $\begin{array}{l}\text { Moisture content =A-B } \\
(\mathbf{g m})\end{array}$ \\
\hline sand & 300 & 265.5 & 34.5 \\
Brick khoa & 591 & 549 & 42 \\
Shingles stone & 712 & 690 & 22 \\
Black stone & 707 & 688 & 19 \\
\hline
\end{tabular}

\subsubsection{Test for Determination of Unit Weight of Aggregate}

A square point shovel, a quartering canvas, a balance, a tamping rod \& measures were the requisite apparatus. The balance or scale was sensitive to $0.5 \%$ of the mass of the sample to be weighed. The Tamping rod, being rounded, straight, steel rod $16 \mathrm{~mm}$ in diameter and approximately 600 $\mathrm{mm}$ in length, has one end rounded to a hemispherical tip of the same diameter as the rod. The cylindrical metal measures with capacities of 0.014 and $0.028 \mathrm{~mm}$, have a metal thickness of $5.3 \mathrm{~mm}$ (reinforced around the upper $38 \mathrm{~mm}$ with a steel band to provide a minimum thickness of $5.3 \mathrm{~mm}$ ). The aggregates to be tested were oven dried to constant mass at $110 \pm 5^{\circ} \mathrm{C}$. Then the measure was placed on a level surface. 
Next the square point shovel was filled from the thoroughly mixed sample pile. After that aggregate was poured from the shovel at a height not exceeding $50 \mathrm{~mm}$ above the top of the measure. This total procedure was repeated until the measure was filled. Then the surface of the aggregate was leveled off with a straight edge in such a way that slight projections of the larger pieces of the coarse aggregate would balance the larger voids in the surface below the top of the measure. Next the total weight of aggregates (W) was calculated. Now the unit weight of aggregate $=\mathrm{W} / \mathrm{V}$

Where, $\mathrm{W}=$ total weight of aggregates in the mould in $\mathrm{kg}$, $\& \mathrm{~V}=$ volume of mould in $\mathrm{m}^{3}$

Table 7. Unit weight of various type of aggregate.

\begin{tabular}{llllll}
\hline $\begin{array}{l}\text { Types of } \\
\text { aggregate }\end{array}$ & $\begin{array}{l}\mathbf{W}(\text { loose)i } \\
\mathbf{n ~ k g}\end{array}$ & $\begin{array}{l}\mathbf{W}(\mathbf{d e n s e}) \mathbf{i} \\
\mathbf{n ~ k g}\end{array}$ & $\mathbf{V}\left(\mathbf{m}^{\mathbf{3}}\right)$ & $\begin{array}{l}\text { Loose unit } \\
\mathbf{w t .}\left(\mathbf{k g} / \mathbf{m}^{\mathbf{3}}\right)\end{array}$ & $\begin{array}{l}\text { Dense unit } \\
\mathbf{w t .}\left(\mathbf{k g} / \mathbf{m}^{\mathbf{3}}\right)\end{array}$ \\
\hline $\begin{array}{l}\text { Brick khoa } \\
\text { Shingles }\end{array}$ & 11.35 & 15.42 & 0.0223 & 508.97 & 691.48 \\
stone & 18.54 & 22.67 & 0.0223 & 831.39 & 1016.59 \\
Black stone & 19.00 & 23.13 & 0.0223 & 852.02 & 1037.22 \\
\hline
\end{tabular}

\subsubsection{Test for Determination of Concrete Crushing Strength}

\section{(i). Working Procedure of Test Specimen}

Cylinders having $150 \mathrm{~mm}$ (6") dia. and $300 \mathrm{~mm}$ (12") height were used for specimen. The following works were performed for the specimen:

1. Preparation of the specimen

2. Curing of the specimen

3. Testing of the specimen

\section{(ii). Preparation \& Curing of Specimen}

1. at first sand was screened by the sieve no.30 $(600 \mu \mathrm{m})$ and aggregates were screened by $1 "(25 \mathrm{~mm})$ and 1/4" $(6.25 \mathrm{~mm})$ sieve.

2. Sand, cement and aggregates were measured dry separately by volume according to the required preparations.

3 . The aggregate were soaked thoroughly in water before use.

4. The fine aggregate (sand), the coarse aggregate were mixed dry on a clean platform.5. Then cement were added and mixed thoroughly once again till the color was uniform.

6 . The required quantity of water was then added gradually and the whole was mixed thoroughly.

7. The mould was smoothened by lubricating oil before the placing of concrete in the mould.

8. The mixtures of concrete placed in the mould of cylinders.

9. The concrete was compacted by tamping rod with 25 blows in three layers and till the water appeared on the top and no aggregates were then left uncover by mortar.

10. Then over 24 hours the moulds were removed and the cylinders cured in water for 7,14 and 28 days to attain its proper strength.

\section{(iii). Testing of the Specimen \\ Apparatus}

The testing machine used to lift the crushing strength of concrete cylinders was a hydraulically operated testing machine of $5000 \mathrm{KN}$ capacity. The rate of loading for this test was controlled at the rate of $10 \mathrm{KN} / \mathrm{sec}$.

\section{Test procedure}

Compression test of moist cured specimens were made after removed from curing place. For the uniform load distribution over the bearing area of specimen sand was used on the both bearing surfaces of each specimen.

\section{Placing of specimen}

The lower bearing plate was placed with its hardened face up on the table of the testing machine directly under the bearing plate. The bearing faces of the test specimen were wiped clear and the test specimen was placed on the lower bearing plate. The axis of the specimen was carefully aligned with the centre of the upper bearing plate.

\section{Crushing of specimen}

The load was applied continuously without shock. It was applied at constant rate of $10 \mathrm{kN} / \mathrm{sec}$. No adjustment was made in the controls of the testing machine while a specimen was yielding rapidly, immediately before failure. The loading was continued until the specimen failed. The maximum load carried by the specimen during the test was recorded. The compressive strength of the specimen was calculated by dividing the maximum load carried by the specimen during the test by the average cross sectional area of the specimen.

Area of cylinder, $\mathrm{A}=(\pi / 4) \times \mathrm{d}^{2}=(3.1416 / 4) \times$ $(150)^{2}=17671.5 \mathrm{~mm}^{2}$

\section{Experimental Results}

Experimental results are shown for compressive strength of various type of concrete with a table below.

Table 8. Compressive strength of various type of concrete.

\begin{tabular}{llll}
\hline \multirow{2}{*}{ Type of aggregate } & \multicolumn{3}{l}{ Compressive strength in MPa } \\
\cline { 2 - 4 } & $\mathbf{7}^{\text {th }}$ days & $\mathbf{1 4}^{\text {th }}$ days & $\mathbf{2 8}^{\text {th }}$ days \\
\hline Brick khoa & 8.92 & 10.35 & 13.87 \\
Shingles stone & 13.92 & 18.22 & 24.64 \\
Black stone & 17.06 & 22.40 & 30.20 \\
\hline
\end{tabular}

Experimental results are shown for compressive strength of various type of concrete with a group by combining strength vs. time curves of concrete for various aggregates, i.e. brick khoa, shingles stone, black stone below.

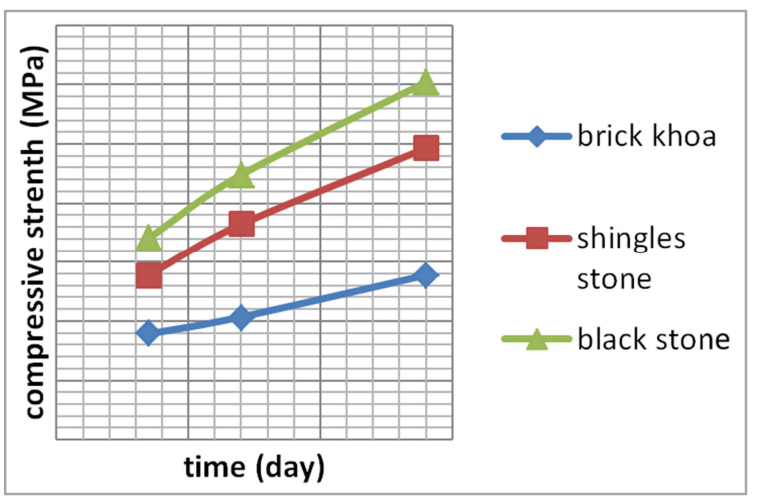

Figure No. 5. Combination of Strength Vs Time curves of concrete (brick khoa, shingles stone, black stone). 
Experimental results are shown for strain analysis of various type of concrete with a table below.

Table 9. Strain analysis of various type of concrete.

\begin{tabular}{|c|c|c|c|c|c|c|c|c|}
\hline \multirow{2}{*}{$\begin{array}{l}\text { Types of } \\
\text { aggregate }\end{array}$} & \multirow{2}{*}{$\begin{array}{l}\text { Length of cylinder, } \\
\text { L(mm) }\end{array}$} & \multicolumn{3}{|l|}{$7^{\text {th }}$ day } & \multicolumn{2}{|l|}{$14^{\text {th }}$ day } & \multicolumn{2}{|l|}{$28^{\text {th }}$ day } \\
\hline & & $\Delta(\mathbf{m m})$ & $\Delta$ & $\varepsilon=\Delta / \mathbf{L}$ & $\Delta(\mathbf{m m})$ & $\varepsilon=\Delta / L$ & $\Delta(\mathbf{m m})$ & $\varepsilon=\Delta / L$ \\
\hline Brick khoa & 300 & 1.50 & & 0.005 & 1.52 & 0.0051 & 1.57 & 0.0052 \\
\hline Shingles stone & 300 & 1.30 & & 0.0043 & 1.40 & 0.0046 & 1.62 & 0.0054 \\
\hline Black stone & 300 & 1.05 & & 0.0035 & 1.30 & 0.0043 & 1.50 & 0.005 \\
\hline
\end{tabular}

Combination of Strength Vs Strain curves of concrete is shown in figure 6.

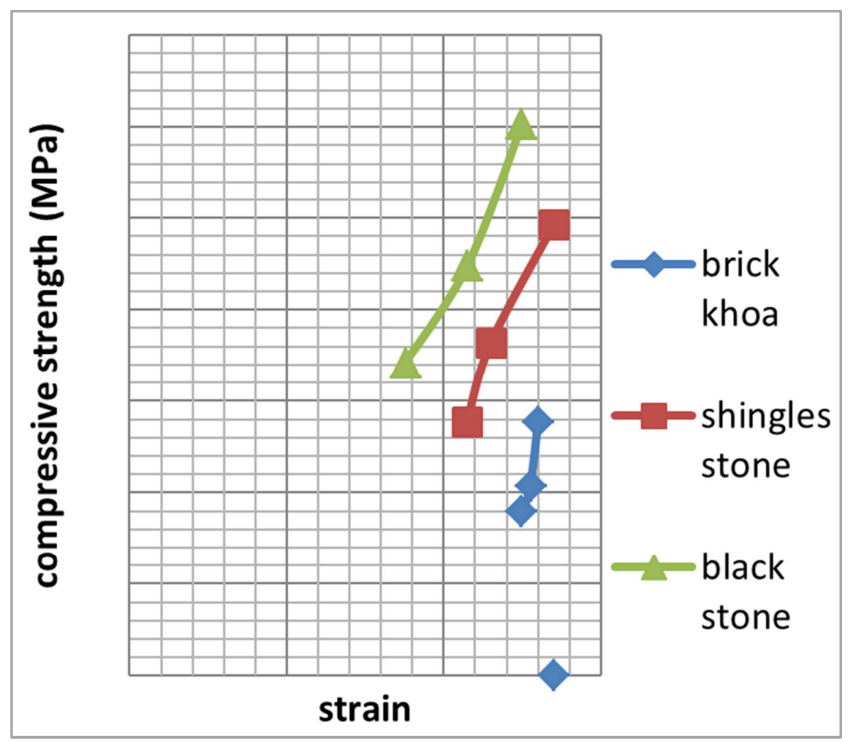

Figure No. 6. Combination of Strength Vs Strain curve of concrete (brick khoa, shingles stone, black stone).

Comparison of aggregate properties (unit weight, crushing strength) with respect to brick aggregate is shown below with a table.

Table No. 10. Comparison of properties of aggregates with respect to brick aggregate.

\begin{tabular}{llll}
\hline $\begin{array}{l}\text { Types of } \\
\text { aggregate }\end{array}$ & $\begin{array}{l}\text { Ratio of unit } \\
\text { weight (dense) of } \\
\text { aggregate with } \\
\text { respect to brick } \\
\text { unit weight }\end{array}$ & $\begin{array}{l}\text { Ratio of } \\
\text { crushing value } \\
\text { of aggregate } \\
\text { with respect to } \\
\text { brick crushing } \\
\text { value }\end{array}$ & $\begin{array}{l}\text { Ratio of crushing } \\
\text { strength of } \\
\text { concrete (28 days) } \\
\text { with respect to } \\
\text { crushing strength } \\
\text { brick }\end{array}$ \\
\hline $\begin{array}{l}\text { Brick khoa } \\
\text { Shingles } \\
\text { stone }\end{array}$ & 1.00 & 1.00 & 1.00 \\
Black stone & 1.47 & 0.85 & 1.78 \\
\hline
\end{tabular}

From table no. 7 \&figure no. 5, it is evident that high unit weight of aggregate produce high crushing strength of concrete. Black stone having highest unit weight 1037.22 $\mathrm{kg} / \mathrm{m}^{3}$ among the considered three aggregates and produce maximum crushing strength $30.20 \mathrm{MPa}$. On the contrary, in case of shingles stone having unit weight $1016.59 \mathrm{~kg} / \mathrm{m}^{3}$, produce concrete crushing strength of $24.64 \mathrm{MPa}$. But only brick shows exceptional result which having lowest unit weight $691.48 \mathrm{~kg} / \mathrm{m}^{3}$ and produce crushing strength 13.87
$\mathrm{MPa}$. For other properties, almost similar results are showed by the aggregates.

\section{Conclusions \& Recommendation}

\subsection{Conclusions}

The fundamental studies on the mechanical properties of aggregate and of hardened cement paste are required to analyze the behavior of concrete specimens. The aggregate is strongly dependent on its parent material and its mechanical properties have big differences from one quarry to another. This paper is expected to be an initial level guideline for the engineers for selecting the aggregates used in normal concrete. However the compatibility tests are absolutely required before the aggregates are used in concrete mixtures.

It was observed that the unit weight of aggregate was not very important for improving the performance of concrete. It was concluded that black stone aggregate having 1.5 times of unit weight than brick aggregate. It is suggested that black stone aggregate may be employed for concrete work in places where concrete practitioners have variety of choices available.

\subsection{Recommendation}

In order to exactly analyze the effect of properties of aggregate on crushing strength of concrete some fundamental studies are still required, i.e., determination of compressive strength, modulus of elasticity and the ductile behavior of aggregate which have to be compared with the behavior of concrete specimen. Also a comparison of strength of concrete mixtures with and without admixtures for various aggregate could be conducted as well as the mechanical model of concrete for verification has already recommended experimental results. The failure of behavior of both aggregates and concrete specimen should be inspected so that their stress - strain curves could be compared decisively each other.

\section{References}

[1] ACI Committee 211.1-91 (1991), Standard Practice for Selecting Proportions for Normal, Heavyweight and Mass Concrete. Detroit, American Concrete Institute.

[2] Meddah, M.S., Zitouni, S., and Belâabes, S., (2010), Effect of Content and Particle Size Distribution of Coarse Aggregate on the Compressive Strength of Concrete, Construction and Building Materials, 24(4), pp 505-512. 
[3] Beshr, H., Almusallam, A.A., and Maslehuddin, M., (2003), Effect of Coarse Aggregate Quality on the Mechanical Properties of High Strength Concrete, Construction and Building Materials, 17(2), pp 97-103.

[4] Abdullahi. M (2012), Effect of aggregate type on compressive strength of concrete, Federal University of Technology P.M.B65, Minna Niger State, Nigeria, ISSN 0976-4399.

[5] Alengaram U.J., Mahmud H., Jumaat M.Z, and Shirazi; S.M., Effect of aggregate size and proportion on strength properties of palm kernel shell concrete, International Journal of the Physical Sciences, 5(12), 1848-1856 (2010).

[6] Neville, A. M. (1995), Properties of concrete, 4th ed. Addison Wesley Longman, England.

[7] Safiqul Islam (2005), A comparative study of aggregate properties and its effect on the crushing strength of concrete, RUET, Rajshahi-6204, Bangladesh.

[8] Dr. M. A. Aziz (1995), A text book of engineering materials, BUET, Dhaka, Bangladesh.

[9] Ayub M., Q. Ali, K. Shahzada, A. Naseer, M. Shoaib and U. Ayub. Engineering assessment of coarse aggregates used in Peshawar. Int. J. Advanced Structures and Geotechnical Eng., 01 (2); 61-64 (2012).

[10] Joseph O. U., E. E. Maurice and A.A. Godwin. Compressive strength of concrete using lateritic sand and quarry dust as fine aggregate. ARPN J. Eng. Appl. Sci., 7(1); 81-92 (2012).

[11] Tasong W., C. Lynsdale and J. Cripps. Aggregate-cement paste interface. Influence of aggregate physical properties. Cement and Concrete Res., 28(10); 1453-1465 (1998).

[12] Makani A. Influence de la nature minéralogique des granulatssur le comportement mécaniquedifféré des bétons. Ph.D Thesis, LMDC, Université de Toulouse, France (2011).

[13] Elsharief A., M. D. Cohen and J. Olek. Influence of aggregate size, water cement ratio and age on the microstructure of the interfacial transition zone. Cement and Concrete Res., 33(11); 1837- 1849 (2003).

[14] Akçaoglu, T., M. Tokyay and T. Çelik. Effect of coarse aggregate size and matrix quality on ITZ and failure behavior of concrete under uniaxial compression. Cement and Concrete Comp., 26(6); 633-638 (2004)

[15] Makani, A., T. Vidal, G. Pons and G. Escadeillas. Time dependent behaviour of high performance concrete: influence of coarse aggregate characteristics. ICEM14 Int. conf. on experimental mechanics, Poitiers (2010).

[16] Basheer, L., P. Basheer and A. Long. Influence of coarse aggregate on the permeation, durability and the microstructure characteristics of ordinary Portland cement concrete. Construction and Building Materials, 19(9); 682-690 (2005). 